\title{
Partial Red Blood Cell Exchange in Children and Young Patients with Sickle Cell Disease: Manual Versus Automated Procedure
}

\section{Transfusão Permuta Parcial em Crianças e Jovens com Doença Falciforme: Comparação da Experiência Manual com o Procedimento Automatizado}

Carlos ESCOBAR ${ }^{1}{ }^{1}$, Marta MONIZ ${ }^{1}$, Pedro NUNES ${ }^{1}$, Clara ABADESSO ${ }^{1}$, Teresa FERREIRA², António BARRA ${ }^{3}$, Anabela LICHTNER ${ }^{3}$, Helena LOUREIRO ${ }^{1}$, Alexandra DIAS ${ }^{2}$, Helena ALMEIDA ${ }^{1}$

Acta Med Port 2017 Oct;30(10):727-733 - https://doi.org/10.20344/amp.8228

\begin{abstract}
Introduction: The benefits of manual versus automated red blood cell exchange have rarely been documented and studies in young sickle cell disease patients are scarce. We aim to describe and compare our experience in these two procedures.

Material and Methods: Young patients ( $\leq 21$ years old) who underwent manual- or automated-red blood cell exchange for prevention or treatment of sickle cell disease complications were included. Clinical, technical and hematological data were prospectively recorded and analyzed.

Results: Ninety-four red blood cell exchange sessions were performed over a period of 68 months, including 57 manual and 37 automated, 63 for chronic complications prevention, 30 for acute complications and one in the pre-operative setting. Mean decrease in sickle hemoglobin levels was higher in automated-red blood cell exchange $(p<0.001)$ and permitted a higher sickle hemoglobin level decrease per volume removed $(p<0.001)$, while hemoglobin and hematocrit remained stable. Ferritin levels on chronic patients decreased $54 \%$. Most frequent concern was catheter outflow obstruction on manual-red blood cell exchange and access alarm on automated-red blood cell exchange. No major complication or alloimunization was recorded.

Discussion: Automated-red blood cell exchange decreased sickle hemoglobin levels more efficiently than manual procedure in the setting of acute and chronic complications of sickle cell disease, with minor technical concerns mainly due to vascular access. The threshold of sickle hemoglobin should be individualized for clinical and hematological goals. In our cohort of young patients, the need for an acceptable venous access was a limiting factor, but iron-overload was avoided.
\end{abstract}

Conclusion: Automated red blood cell exchange is safe and well tolerated. It permits a higher sickle hemoglobin removal efficacy, better volume status control and iron-overload avoidance.

Keywords: Adolescent; Anemia, Sickle Cell; Child; Erythrocyte Transfusion/methods; Young Adult

\section{RESUMO}

Introdução: Os benefícios da transfusão permuta parcial manual versus automatizada encontram-se pouco documentados e existem poucos estudos em jovens com doença falciforme. Pretendemos descrever e comparar a nossa experiência com os dois procedimentos.

Material e Métodos: Foram incluídos jovens ( $\leq 21$ anos) que realizaram transfusão permuta parcial-manual ou -automatizada para prevenção ou tratamento de complicações da doença falciforme. Dados clínicos, técnicos e valores hematológicos foram recolhidos de forma prospectiva e analisados.

Resultados: Realizaram-se 94 transfusões permuta parcial num período de 68 meses, 57 manuais e 37 automatizadas, 63 para prevenção de complicações crónicas, 30 por complicações agudas e uma no contexto pré-operatório. A redução média da hemoglobina $S$ foi superior na transfusão permuta parcial-automatizada $(p<0,001)$ e permitiu uma redução de hemoglobina $S$ por volume permutado superior $(p<0,001)$, mantendo valores de hemoglobina e hematócrito estáveis. Os valores de ferritina dos doentes crónicos diminuíram em 54\%. A principal preocupação foi a obstrução do lúmen do cateter na transfusão permuta parcial-manual e os alarmes de pressão do acesso na transfusão permuta parcial-automatizada. Não houve complicações major nem aloimunização.

Discussão: A transfusão permuta parcial-automatizada reduziu a hemoglobina $S$ de forma mais eficiente que a transfusão permuta parcial-manual em doentes com complicações da doença falciforme, existindo pequenos problemas relacionados com o acesso vascular. O valor alvo de hemoglobina S deve ser individualizado segundo a clínica e os objetivos hematológicos. Na nossa coorte de jovens, a necessidade de um acesso venoso aceitável foi a principal limitação, mas a sobrecarga de ferro foi evitada.

Conclusão: A transfusão permuta parcial automatizada é segura e bem tolerada. Permite uma maior eficácia na redução da hemoglobina S, um melhor controlo da volemia e a evicção da sobrecarga de ferro.

Palavras-chave: Adolescente; Adulto Jovem; Anemia Falciforme; Criança; Transfusão de Eritrócitos/métodos

\section{INTRODUCTION}

Sickle cell disease (SCD) is one of the commonest genetic disorders causing severe disease. To date no therapy is completely effective in the prevention and

treatment of SCD complications. Transfusion in SCD aims to improve oxygen-carrying capacity while reducing the circulating level of sickle hemoglobin $(\mathrm{HbS})$ and increasing

1. Unidade de Cuidados Intensivos e Especiais Pediátricos. Departamento de Pediatria. Hospital Prof. Doutor Fernando Fonseca. Amadora. Portugal.

2. Hematologia Pediátrica. Departamento de Pediatria. Hospital Prof. Doutor Fernando Fonseca. Amadora. Portugal.

3. Serviço de Sangue e Medicina Transfusional. Hospital Prof. Doutor Fernando Fonseca. Amadora. Portugal.

$\square$ Autor correspondente: Carlos Escobar. carlos.g.escobar@hff.min-saude.pt

Recebido: 19 de setembro de 2016 - Aceite: 20 de junho de 2017 | Copyright @ Ordem dos Médicos 2017 
hemoglobin $A$, thus reducing impaired erythropoiesis, hemolysis and vaso-occlusive events, which are the main contributors for complications of SCD. ${ }^{1}$

Red blood cell exchange (RBCX) in SCD removes abnormal red blood cells (RBC) and replaces them with donor RBCs, and is probably an underused technique. Compared to simple transfusion, RBCX prevents volume overload and viscosity rising, and is the only technique that rapidly decreases the levels of $\mathrm{HbS}^{2}$

Indications for RCBX have been classified by the evidence-based guidelines of the American Society for Apheresis (ASFA) into 4 categories $^{3}$, and are summarized in Table 1. However, other indications may be considered attending to current literature: recurrent acute chest syndromeand recurrent vaso-occlusive crises not responsive to hydroxicarbamide, acute hepatic sequestration, leg ulcer, pulmonary hypertension, end-stage renal disease and progressive proliferative retinopathy. $2,4-9$

To date, the benefits of manual versus automated RBCX have rarely been documented and studies in young patients are scarce. The safety and tolerability profile of automated $\mathrm{RCBX}$ procedures have been extensively reported in singlecenter experiences showing a good profile in children and adults. ${ }^{10-13}$

We aim to describe our pediatric experience in the management of SCD complications with the use of an automated RBCX (A-RBCX) program and compare it to our previous manual partial RBCX (M-RBCX) experience.

\section{MATERIAL AND METHODS}

\section{Patients and variables}

We included all children and young adults $(\leq 21$ years old) with SCD who underwent manual or automated RBCX between January 2011 and August 2016 for prevention or treatment of complications of SCD.

Data were prospectively collected into a database as part of patient follow-up. Variables considered were: clinical (gender, age, weight, indication), laboratory (hematocrit$\mathrm{Htc}$, hemoglobin- $\mathrm{Hb}, \mathrm{HbS} \%, \mathrm{HbF} \%$, platelet count), packed RBC use, technical data (ports, duration) and complications.

\section{Indications and definitions}

Our protocol for RBCX in SCD contemplates the following indications:

\section{1) Acute SCD complications:}

- Stroke: persistent neurological abnormality or transient symptoms accompanied by a new cerebral lesion on neuroimaging studies.

- Acute chest syndrome (ACS): infiltrate on x-ray (consolidation), accompanied by: chest pain, fever, tachypnea, wheezing or cough. Severity was considered when increased oxygen needs or mechanical respiratory support was started.

- Vaso-occlusive crisis (VOC) refractory to standard treatment: clinically assessed painful crisis with no adequate pain control after standard measures and optimized opioid perfusion.

\section{2) Chronic SCD complications:}

- Primary stroke prevention: when high blood flow velocities more than $200 \mathrm{~cm} / \mathrm{s}$ on trans-cranial Doppler are detected.

- Secondary stroke prevention: after acute or overt stroke, as shown in neuroimaging studies (magnetic resonance / angiogram).

- Recurrent acute complications: VOC, ACS or priapism.

3) In the pre-operative setting of major surgery.

Other indications are considered and individualized after discussion with pediatric hematology consultants.

Goals for $\mathrm{HbS}$ level are under $30 \%$ for acute stroke and stroke prevention, and $30 \%-50 \%$ in the other acute and chronic complications.

Table 1 - Indications for therapeutic apheresis: ASFA 2010 categories $^{3}$

\begin{tabular}{|c|c|c|c|}
\hline ASFA category & \multicolumn{3}{|l|}{ Description } \\
\hline I & \multicolumn{3}{|c|}{$\begin{array}{l}\text { Apheresis is accepted as first-line therapy, either as primary standalone treatment or in conjunction with other } \\
\text { modes of treatment. }\end{array}$} \\
\hline II & \multicolumn{3}{|c|}{$\begin{array}{l}\text { Apheresis is accepted as second-line therapy, either as primary standalone treatment or in conjunction with } \\
\text { other modes of treatment. }\end{array}$} \\
\hline III & \multicolumn{3}{|c|}{ Optimum role of apheresis therapy is not established. Decision making should be individual } \\
\hline \multicolumn{2}{|c|}{ SCD complication } & Acute RCBX & Chronic/ Non-acute RCBX \\
\hline \multicolumn{2}{|l|}{ Acute stroke } & I & \\
\hline \multicolumn{2}{|c|}{ Acute chest syndrome, severe } & II & \\
\hline \multicolumn{2}{|c|}{ Multisystem organ failure } & III & \\
\hline \multicolumn{2}{|c|}{ Severe intrahepatic cholestasis } & III & \\
\hline \multicolumn{2}{|l|}{ Priapism } & III & \\
\hline \multicolumn{3}{|c|}{ Stroke prevention with iron overload prevention } & II \\
\hline \multicolumn{3}{|c|}{ Vaso-occlusive pain } & III \\
\hline \multicolumn{3}{|l|}{ Presurgery } & III \\
\hline
\end{tabular}




\section{Procedure description}

Ethical considerations: informed consent was obtained from the legal tutors or from the patient over 18 years old before the procedure.

Blood product preparation: extended blood group phenotyping $[A B O, \operatorname{Rh}(D, C, C, E, e), K, J k(a), J k(b), F y(a)$, $\mathrm{Fy}(\mathrm{b})$ and others] and antibody screening was performed to each patient prior to RBCX. Packed RBC units used are HbS-negative, leucodepleted at the time of donation and irradiated (except in emergency setting). A limited donor policy and Duffy group genotyping (FYB gene) 14 for each patient is in place in our hospital Blood Bank, in collaboration with the Portuguese Institute for Blood and Transplantation (IPST, IP).

Local and monitoring: all patients were admitted to our Intensive Care unit and had clinical and continuous cardiorespiratory monitoring before, during and immediately after the procedure (heart rate, respiratory rate, oxygen saturation, blood pressure, temperature). When considered clinically necessary, more than one procedure was performed.

\section{Procedure:}

- Ports: a transfusion and blood removal port were placed. The type of venous access was recorded for each patient.

- Manual RBCX procedure: continuous isovolemic exchange, of venesected blood for $10-15 \mathrm{~mL} / \mathrm{kg}$ of packed RBC and a concomitant saline infusion, aiming to maintain a low hematocrit similar to the patient's initial hematocrit. No limitation on patient weight is considered.

- Automated RBCX procedure: Spectra Optia ${ }^{\circledR}$ Apheresis System (Terumo BCT) with a dedicated RBCX kit is in place in our PICU since December 2014. Calcium citrate anticoagulation in a $13: 1$ ratio is used. Exchange or depletion+exchange (isovolemic hemodilution) protocol was used according to the patients initial Htc and clinical situation. A personalized priming of the circuit with $5 \%$ albumin or blood must be performed for patients with a programmed extracorporeal exchange volume over $10 \%-15 \%$ of the total blood volume (Spectra Optia ${ }^{\circledR}$ Operators Manual, 2015).

Laboratory tests: previous to the procedure and four to eight hours after procedure a complete blood count, reticulocyte count, $\mathrm{HbS}$ and $\mathrm{HbF}$ levels were obtained. lonized serum calcium was measured when symptoms of hypocalcemia were present. Serum ferritin was obtained prior to RBCX in chronic patients.

\section{Outcomes}

The primary outcome of the study was $\mathrm{HbS}$ level variation after $\mathrm{M}$ - and $\mathrm{A}-\mathrm{RBCX}$.

The secondary outcomes were: technique indications; effect of RBCX on $\mathrm{Hb}$, hematocrit, platelet count and $\mathrm{HbF}$ level; packed RBC utilization and efficiency; technical concerns and complications associated with vascular access and RCBX procedure.

\section{Statistical analysis}

Data are presented as mean \pm standard deviation (SD) when the distribution was normal and median (range) when not normal. Normality was assessed using Shapiro-Wilk test. Manual and automated procedures were compared. The comparison of continuous variables was accomplished with parametric test Student's $t$ test when normality was assured. The comparison of categorical data in two-way contingency tables was performed using Fisher test. Statistical significance level was set at $p=0.05$. Statistical software SPSS for Windows v19.0 was used.

\section{RESULTS}

\section{Cohort characteristics and indication for RBCX}

Ninety-four RBCX sessions were performed in 16 patients over a period of 68 months. All patients were homozygous for $\mathrm{HbS}$ (HbSS) and with African family origin. The age ranged from 5 to 21 years old (median: 12 years old) and weight ranged 15 to $63 \mathrm{~kg}$ (median: $30 \mathrm{~kg}$ ). Fifteen patients were taking hydroxicarbamide before RBCX.

The median number of procedures per patient was two (range: 1 - 48 sessions), with nine patients performing only one or two RBCX and seven patients had three or more RBCX sessions.

RBCX were manually performed in 57 sessions and 37 were automated. There were statistically significant differences in terms of age and weight in both groups. Gender distribution, chronic indication frequency, pre-RBCX hematological values and procedure duration were similar. The characteristics of each group are presented in Table 2.

In 63 cases the procedures were indicated for prevention

Table 2 - Characteristics of RBCX groups

\begin{tabular}{lccc} 
& $\begin{array}{c}\text { M-RBCX } \\
(\mathbf{n}=\mathbf{5 7})\end{array}$ & $\begin{array}{c}\text { A-RBCX } \\
(\mathbf{n}=\mathbf{3 7})\end{array}$ & $\boldsymbol{p}$-value \\
\hline Chronic indication & $63.2 \%$ & $73.0 \%$ & $0.260^{*}$ \\
Pre-RBCX Hb (g/dL) & $8.2 \pm 0.9$ & $8.3 \pm 1.0$ & $0.374 \dagger$ \\
Pre-RBCX Htc (\%) & $23.7 \pm 3$ & $23.3 \pm 2.7$ & $0.516 \dagger$ \\
Pre-RBCX HbS (\%) & $60.3 \pm 11.9$ & $65.9 \pm 14.4$ & $0.047 \dagger$ \\
RBCX procedure time (minutes) & $89 \pm 28$ & $95 \pm 39$ & $0.419 \dagger$ \\
& (range: $55-180)$ & (range: $33-196)$ & 1 nurse for monitoring and alarm control \\
Human resources & 1 dedicated nurse & 1 supervising doctor \\
\hline
\end{tabular}


Table 3 - Indications for RBCX in our cohort by technique

\begin{tabular}{|c|c|c|c|}
\hline & M-RBCX & A-RBCX & Total \\
\hline Acute complications & 21 & 9 & 30 \\
\hline Acute chest syndrome & 10 & 2 & 12 \\
\hline Refractory VOC & 4 & 5 & 9 \\
\hline$A C S+$ refractory $V O C$ & 5 & 0 & 5 \\
\hline Priapism & 1 & 1 & 2 \\
\hline Acute stroke & 1 & - & 1 \\
\hline Extensive subgaleal hematoma due to extramedullary hematopoiesis & - & 1 & 1 \\
\hline Chronic complications & 36 & 27 & 63 \\
\hline Secondary stroke prevention* & 35 & 16 & 51 \\
\hline Primary stroke prevention & 1 & 7 & 8 \\
\hline Recurrent VOC & 0 & 4 & 4 \\
\hline Recurrent priapism* & 0 & 5 & 5 \\
\hline Pre-operative & - & 1 & 1 \\
\hline
\end{tabular}

of chronic complications, in 30 for acute complications and one procedure in the pre-operative setting of laparoscopic cholecystectomy. The chronic and acute indications for RBCX in our cohort are summarized in Table 3.

The median follow-up for chronic patients was six months (range: 2 - 60 months). One young adult patient with overt stroke and recurrent priapism episodes was lost to follow-up after five A-RBCX sessions.

\section{Vascular access}

The most common venous port used for blood removal was central venous catheter (CVC) (84 sessions, 89.4\%). In ten cases of RBCX the same CVC with two lumens was used for both blood removal and transfusion, and in eight cases two CVC had to be placed. Peripheral access was only used for blood removal in two cases of M-RBCX and was tried in four cases of A-RBCX without success due to its low blood outflow. Peripheral venous access for transfusion was used in 44 sessions (46.8\%).

Only one patient had long-term port placed for transfusion for secondary stroke prevention in RBCX program: one was used for $14 \mathrm{M}-\mathrm{RBCX}$ sessions before being removed due to infection and a second one was used for 18 sessions. In this same patient, an arteriovenous fistula (AVF) in the forearm was created as a venous access for RBCX and was used in three manual procedures for bleeding and transfusion before AVF thrombosis.

\section{Hematological outcomes}

The mean decrease in $\mathrm{HbS}$ levels was higher in A-RBCX procedures $(-46 \%$ vs $-27 \% ; p<0.001)$ while hemoglobin and hematocrit remained stable in both procedures (Table 4). The platelet count was highly decreased during automated sessions when compared to manual procedure $(-33 \%$ vs $-20 \% ; p<0.001)$ but platelet count lower than $100000 /$ $\mathrm{mm}^{3}$ did not occur. In $34 \mathrm{~A}-\mathrm{RBCX}$ procedures $\mathrm{HbF}$ levels were recorded before and after the procedure, with a mean decrease of $47.6 \%$.

Ferritin levels were recorded for the five patients on the chronic transfusion program. One patient with concomitant ulcerative colitis has persistent low ferritin values due to frequent gastro-intestinal bleeding, and was not considered. One patient presented with iron overload with ferritin levels over $1400 \mathrm{ng} / \mathrm{mL}$ at the start of the RBCX program and was treated with deferoxamine plus A-RBCX during one year with a reduction and stabilization of ferritin serum levels to $300 \mathrm{ng} / \mathrm{mL}$. The other three patients had received simple transfusions prior to chronic A-RBCX and ferritin levels reduced (median: initial serum ferritin: $223 \mathrm{ng} / \mathrm{mL}$, last ferritin value: $112 \mathrm{ng} / \mathrm{mL}$, variation: $-54 \%$ ) after a median of five A-RBCX sessions.

\section{Packed red cell use and efficiency}

The mean blood consumption of packed RBC per patient weight was $10.5 \pm 3.3 \mathrm{~mL} / \mathrm{kg}$ in M-RBCX and $19.7 \pm$ $6.2 \mathrm{~mL} / \mathrm{kg}$ in A-RBCX $(p<0.001)$. Isovolemic hemodilution

Table 4 - Hematological outcomes in manual and automated RBCX (Mean \pm SD)

\begin{tabular}{|c|c|c|c|c|c|c|c|}
\hline & \multicolumn{2}{|c|}{ Pre-RBCX* } & \multicolumn{2}{|c|}{ Post-RBCX } & \multicolumn{3}{|c|}{ Variation } \\
\hline & M-RBCX & A-RBCX & M-RBCX & A-RBCX & M-RBCX & A-RBCX & $p$-value (t-test) \\
\hline $\mathrm{Hb}(\mathrm{g} / \mathrm{dL})$ & $8.6 \pm 0.6$ & $8.4 \pm 0.9$ & $9.3 \pm 0.7$ & $8.6 \pm 0.8$ & $+7.2 \pm 5.3 \%$ & $+2.1 \pm 11.2 \%$ & 0.284 \\
\hline Htc $(\%)$ & $24.4 \pm 1.9$ & $23.5 \pm 2.5$ & $25.4 \pm 2.4$ & $23.8 \pm 2.1$ & $+4.1 \pm 3.7 \%$ & $+2.5 \pm 11.6 \%$ & 0.374 \\
\hline $\mathrm{HbS}(\%)$ & $56.0 \pm 9.2$ & $66.3 \pm 14.6$ & $41.3 \pm 11.1$ & $35.8 \pm 11.4$ & $-27.2 \pm 7.8 \%$ & $-46.2 \pm 11.0 \%$ & $<0.001$ \\
\hline $\mathrm{HbF}(\%) \dagger$ & $9.7 \pm 4.2$ & $10.9 \pm 6.4$ & $7.9 \pm 4.0$ & $5.6 \pm 3.3$ & $-18.8 \pm 24.0 \%$ & $-47.6 \pm 17.0 \%$ & 0.002 \\
\hline Platelets $\left(10^{3} / \mathrm{uL}\right)$ & $338 \pm 49$ & $393 \pm 159$ & $268 \pm 47$ & $256 \pm 100$ & $-20.3 \pm 10.2 \%$ & $-32.8 \pm 15.0 \%$ & $<0.001$ \\
\hline
\end{tabular}

* simple transfusion previous to RBCX was performed in 14 cases; $\uparrow$ values available for 34 procedures: 5 in M-RBCX \& 29 in A-RBCX 
(depletion + exchange protocol) on A-RBCX was used in 14 sessions (38\% of A-RBCX procedures), with a median use of $115 \mathrm{~mL}$ of saline (range: $50-360 \mathrm{~mL}$ ) in each procedure.

A-RBCX permitted a higher decrease of $\mathrm{HbS}$ level per volume removed $(-2.1 \pm 0.6 \%$ per $\mathrm{mL} / \mathrm{kg}$ of volume removed vs $-1.3 \pm 0.6 \%$ per $\mathrm{mL} / \mathrm{kg} ; p<0.001$ ) although removal volumes were equal between RBCX procedures (23.8 \pm $12.2 \mathrm{~mL} / \mathrm{kg}$ in M-RBCX vs $23.1 \pm 6.3 \mathrm{~mL} / \mathrm{kg}$ in A-RBCX; $p=$ $0.500)$. Removal volume in $\mathrm{M}-\mathrm{RBCX}$ consists of venesected total blood while on A-RBCX is mainly the RBC fraction after centrifugation.

\section{Procedure concerns and complications}

Vascular access management was the most frequent concern during procedures: catheter outflow obstruction in manual blood removal ( $n-8)$, solved after saline wash-out of the circuit or replacement of stopcock and extension tubing; access alarm on A-RBCX equipment due to excessive pressure in return or removal circuit ( $n-7)$, solved changing the patient position, flushing the catheter with saline, decreasing the inlet rate, or reversing the catheters lumens when the same port was used for transfusion and removal.

Other vascular port related complications were implantable venous port infection $(n-1)$ and AVF thrombosis $(n-1)$, and both occurred in the same patient while on the M-RBCX program.

Other minor complications included hypotension $(n-3)$ and transitory hypothermia ( $n-1)$, both in M-RBCX. There were no metabolic or electrolyte imbalances, as well as no symptoms of acute hypocalcemia.

After 154 packed RBC units transfused in RBCX, there was no record of alloantibodies development or transfusion reactions.

\section{DISCUSSION}

In this study, we present our single-center cohort experience of RBCX procedures for the prevention and treatment of SCD complications in young patients. To our knowledge, this is the only report of pediatric $A-R B C X$ experience in Portugal.

We aimed to compare our manual vs automated RBCX experience, and although there were statistically diferences in terms of age and weight between both groups, we did not find that those differences affected the patient management.

In our cohort, A-RBCX decreased HbS levels more efficiently than manual procedure in the setting of acute and chronic complications of SCD, with minor technical concerns mainly due to vascular access difficulty. This further reduction in $\mathrm{HbS}$ observed with automated procedures is explained not only by the greater amount of packed RBC used, but also because A-RBCX permits the separation of the RBC fraction of blood and reutilization of the patients own plasma, thus allowing higher exchange volumes. In both procedures, hemoglobin and hematocrit remained in the expected ranges, which allowed overcoming the hyperviscosity associated with simple transfusion.

A threshold for $\mathrm{HbS}$ level under $30 \%$ has been recommended for patients with complications of SCD. ${ }^{2}$ However, some authors agree that a higher threshold between $40 \%$ - 50\% may be acceptable in patients without recurrence of stroke in the first 24 months, patients with only abnormal TCD results or patients with acute complications besides stroke. ${ }^{15,16}$ For patients with recurrent VOC a threshold of $<50 \%$ has been proposed. ${ }^{2}$ Achieving a $\mathrm{HbS}$ level threshold of $30 \%$ or less may be associated with higher blood requirements and more frequent RBCX procedures and in our opinion the $\mathrm{HbS}$ threshold should be individualized according with clinical goals, especially in the acute setting. The higher packed RBC volume needed to perform A-RBCX could represent a concern for blood banks in some centers.

A higher platelet removal in the automated technique could be a limitation to remove higher blood volumes, but in our cohort we did not find any severe thrombocytopenia. The clinical significance of the reduction $\mathrm{HbF}$ levels in patients enrolled in the chronic RBCX program is unknown, and should be further analyzed.

Regarding ACS treatment, the better control of hyperviscosity and volume status associated with $\mathrm{RBCX}$ favors the use of this technique instead of simple transfusion as the first-line therapy in moderate and severe cases, when a rapid decrease in $\mathrm{HbS}$ is needed, and also in patients with a high baseline $\mathrm{Hb}$ value..$^{2,9,17}$

Albeit not consensual, in our opinion RBCX should also be considered as an additional therapy for refractory pain due to VOC after optimization of opioid infusion. A higher depuration of opioids during the procedure should be taken into account and analgesia should be monitored, although in our experience we did not find it a relevant issue once improvement of complaints was registered a few hours after RBCX and opioids could be decreased.

For children and young adults included in chronic transfusion programs, the need for an acceptable venous access can be a limiting factor, with a high rate of central port placement. 8,10 Moreover, sedation and expertise for central line insertion requires a trained healthcare team. In our institution, children on the chronic RBCX program are admitted to PICU for 24 hours or less to perform the procedure. Blood removal in RBCX requires a good blood outflow that we were not able to achieve with peripheral venous access, probably due to vein size and cannulation difficulties. In the experience of other authors, arteriovenous fistula, long-term dual lumen implantable ports or even peripheral access have proved successful in adults ${ }^{16,18}$ and children $^{8}$ with SCD in chronic erythrocytapheresis programs. Our AVF attempt was not successful, probably due to the size of the patient, and a long-term single-port subcutaneous catheter was placed in this child.

Alloimmunization has been a frequently described complication of multiple transfusions in adults with SCD. ${ }^{9}$ This complication is especially important in countries like Portugal, with donors mainly of Caucasian origin and sickle cell patients of African origin. In our experience no cases of alloantibodies were found, probably due to an 
extensive blood group matching and limited donor policy. Nevertheless, recent literature in SCD patients has proved that RBCX does not increase the risk of alloimmunization even though the blood requirement and donor exposure is higher. ${ }^{19-20}$

Although not a main endpoint of our study, ferritin levels of our patients on chronic RBCX were always in the normal range and so no iron-overload complications were observed. One patient needed chelation therapy with deferasirox, due to multiple single transfusions as part of the chronic transfusion program for secondary prevention of stroke that was performed before starting RCBX. After starting the monthly A-RBCX program a decrease in ferritin levels was observed and chelation therapy was stopped. Iron overload is directly associated with transfusion method and its duration, ${ }^{21}$ and can have serious longterm consequences during adulthood, including hepatic cirrhosis, cardiac damage, diabetes, hypogonadism and pulmonary hypertension. ${ }^{22-24} \mathrm{~A}-\mathrm{RBCX}$ is the method that is associated with the lowest iron accumulation rate of all transfusion regimens ${ }^{24}$ and has also proved to be an effective method to reduce iron overload in chronically transfused patients. ${ }^{25}$ Prevention of iron overload instead of treating its consequences is a major health goal in our care for children with sickle cell disease.

Despite the fact that A-RBCX is easier to perform and less human resource consuming, it is not feasible in all settings due to the need of specific and expensive equipment. In this context, manual RBCX still has a role in centers without apheresis systems. In our experience, this is a feasible and safe procedure that can be readily performed in the setting of acute complications of SCD to lower $\mathrm{HbS}$ levels. ${ }^{26}$ However, in the long-term and whenever available, automated procedures should be preferred for their ability

\section{REFERENCES}

1. Swerdlow PS. Red cell exchange in sickle cell disease. Hematology Am Soc Hematol Educ Program. 2006;48-53.

2. Kim HC. Red cell exchange: special focus on sickle cell disease. Hematology Am Soc Hematol Educ Program. 2014;2014:450-6.

3. Schwartz J, Winters JL, Padmanabhan A, Balogun RA, Delaney M, Linenberger ML, et al. Guidelines on the use of therapeutic apheresis in clinical practice-evidence-based approach from the Writing Committee of the American Society for Apheresis: the sixth special issue. J Clin Apher. 2013;28:145-284.

4. Cabibbo S, Fidone C, Garozzo G, Antolino A, Manenti GO, Bennardello $\mathrm{F}$, et al. Chronic red blood cell exchange to prevent clinical complications in sickle cell disease. Transfus Apher Sci. 2005;32:315-21.

5. Josephson CD, Su LL, Hillyer KL, Hillyer CD. Transfusion in the patient with sickle cell disease: a critical review of literature and transfusion guidelines. Transf Med Rev. 2007;21:118-33.

6. Wun T, Hassell K. Best practices for transfusion for patients with sickle cell disease. Hematol Rev. 2009;1:e22

7. McKinney CM, Siringo F, Olson JL, Capocelli KE, Ambruso DR, Nuss R. Red cell exchange transfusion halts progressive proliferative sickle cell retinopathy in a teenaged patient with hemoglobin SC disease. Pediatr Blood Cancer. 2015;62:721-3.

8. Aloni MN, Lê PQ, Heijmans C, Huybrechts S, Devalck C, Azzi N, et al. A pilot study of manual chronic partial exchange transfusion in children with sickle disease. Hematology. 2015;20:284-8.

9. Chou ST, Fasano RM. Management of patients with sickle cell disease using transfusion therapy: guidelines and complications. Hematol Oncol Clin North Am. 2016;30:591-608.

10. Filhon B, Dumesnil C, Holtermann C, Bastit D, Schneider P, Vannier to maintain lower $\mathrm{HbS}$ values, to allow more spaced procedures and avoid iron-overload. ${ }^{11}$ Further studies should address other indications for RCBX, especially in the pediatric population where prevention should start as early as needed.

\section{CONCLUSION}

Partial red cell exchange was shown to be a safe and well tolerated technique for the prevention and treatment of complications of sickle cell disease in our cohort. A higher $\mathrm{HbS}$ removal efficacy, better volume status control and iron-overload avoidance makes automated RBCX a prefered technique than compared to manual partial RBCX and should always be preferred in long-term transfusion programs.

\section{PROTECTION OF HUMANS AND ANIMALS}

This study was conducted in accordance with the principles of the Declaration of Helsinki, ICH Guidelines for Good Clinical Practice and in full conformity with relevant regulations. Patients provided written informed consent for study participation. The study protocol was approved by the local ethics committee.

\section{DATA CONFIDENTIALITY}

The authors declare having followed the protocols in use at their working center regarding patients' data publication.

\section{CONFLICTS OF INTEREST}

All authors report no conflict of interest.

\section{FUNDING SOURCES}

This work received no specific grant from any funding agency in the public, commercial, or not-for-profit sectors.

JP. Intérêt et difficultés de l'érythraphérèse chez les patients drépanocytaires: à propos d'une expérience pédiatrique. Arch Pediatr. 2012;19:572-8.

11. Duclos C, Merlin E, Paillard C, Thuret I, Demeocq F, Michel G, et al. Long-term red blood cell exchange in children with sickle cell disease: manual or automatic? Transfus Apher Sci. 2013;48:219-22.

12. Quirolo K, Bertolone S, Hassell K, Howard T, King KE, Rhodes DK, et al. The evaluation of a new apheresis device for automated red blood cell exchange procedures in patients with sickle cell disease. Transfusion. 2015;55:775-81.

13. Tsitsikas DA, Sirigireddy B, Nzouakou R, Calvey A, Quinn J, Collins J, et al. Safety, tolerability, and outcomes of regular automated red cell exchange transfusion in the management of sickle cell disease. $\mathrm{J}$ Clin Apher. 2016;31:545-50.

14. Costa C, Lichtner A, Rodrigues MJ, Moser MI, Barra A, Cardoso E, et al. Importância da genotipagem na terapêutica transfusional de doentes com drepanocitose. Associação Portuguesa de Imuno-Hemoterapia. 2015. [accessed 2017 Sep 1]. Available from: http://hdl.handle. net/10400.10/1540.

15. Miller ST. How I treat acute chest syndrome in children with sickle cell disease. Blood. 2011;117:5297-305.

16. Koehl B, Sommet J, Holvoet L, Abdoul H, Boizeau P, Ithier G, et al Comparison of automated erythrocytapheresis versus manual exchange transfusion to treat cerebral macrovasculopathy in sickle cell anemia. Transfusion. 2016;56:1121-8.

17. Saylors RL, Watkins B, Saccente S, Tang X. Comparison of automated red cell exchange transfusion and simple transfusion for the treatment of children with sickle cell disease acute chest syndrome. Pediatr Blood 
Cancer. 2013;60:1952-6.

18. Shrestha A, Jawa Z, Koch KL, Rankin AB, Xiang Q, Padmanabhan A, et al. Use of a dual lumen port for automated red cell exchange in adults with sickle cell disease. J Clin Apher. 2015;30:353-8.

19. Wahl SK, Garcia A, Hagar W, Gildengorin G, Quirolo K, Vichinsky E. Lower alloimmunization rates in pediatric sickle cell patients on chronic erythrocytapheresis compared to chronic simple transfusions. Transfusion. 2012;52:2671-6.

20. Michot JM, Driss F, Guitton C, Moh Klaren J, Lefebvre F, Chamillard X, et al. Immunohematologic tolerance of chronic transfusion exchanges with erythrocytapheresis in sickle cell disease. Transfusion. 2015;55:357-63.

21. Kim HC, Dugan NP, Silber JH, Martin MB, Schwartz E, OheneFrempong K, et al. Erythrocytapheresis therapy to reduce iron overload in chronically transfused patients with sickle cell disease. Blood. 1994;83:1136-42.

22. Adamkiewicz TV, Abboud MR, Paley C, Olivieri N, Kirby-Allen M,
Vichinsky E, et al. Serum ferritin level changes in children with sickle cell disease on chronic blood transfusion are nonlinear and are associated with iron load and liver injury. Blood. 2009;114:4632-8.

23. Raghupathy $R$, Manwani D, Little JA. Iron overload in sickle cell disease. Adv Hematol. 2010;2010:272940.

24. Porter J, Garbowski M. Consequences and management of iron overload in sickle cell disease. Hematology Am Soc Hematol Educ Program. 2013;2013:447-56.

25. Fasano RM, Leong T, Kaushal M, Sagiv E, Luban NL, Meier ER Effectiveness of red blood cell exchange, partial manual exchange, and simple transfusion concurrently with iron chelation therapy in reducing iron overload in chronically transfused sickle cell anemia patients. Transfusion. 2016;56:1707-15.

26. Escobar C, Moniz M, Mascarenhas I, Silvestre C, Nunes P, Abadesso C, et al. Transfusão Permuta Parcial no Tratamento de Complicações Agudas na Drepanocitose. Acta Pediatr Port. 2015;46:205-10. 